\title{
Port Service Quality Study of Nigerian Sea Ports
}

\author{
Chinedum Onyemechi ${ }^{1}$, Azubuike Chibuzo Amanze ${ }^{1}$, Chinemerem Igboanusi ${ }^{2}$ and Abiodun Sule $^{3}$ \\ 1. Dept. of Maritime Management Technology, Federal University of Technology Owerri, P.M.B 1526 Owerri, Imo State, Nigeria \\ 2 Dept. of Transport Management Technology, Federal University of Technology Owerri, P.M.B 1526 Owerri, Imo State, Nigeria \\ 3. Federal College of Fisheries and Marine Technology, Victoria Island 2 Wilmot Point Road, Off Ahmadu Bello Way, P.M.B. 80063, \\ Victoria Island, Lagos, Nigeria
}

\begin{abstract}
This study is focused on service quality assessment in the Nigerian ports with Western and Eastern port zones as study areas. It discovered the level of satisfaction derived by port users by evaluating expectations and perceptions at the ports using some selected analysis tools to test raised hypothesis. This evaluation was based on the service quality model as developed by Parasuraman within the core dimensions of Empathy, Responsiveness, Tangibles, Reliability and Assurance. The attributes of expectations and perceptions raised within these dimensions were addressed with two hypotheses. H1 (Hypothesis one) and H2 (Hypothesis two) were addressed with the results of Factor Analysis which identified the significance port users attach to service quality dimensions and their respective attributes.
\end{abstract}

Key words: Service quality, port, expectation, perception.

\section{Introduction}

Among other critical port success factors, service quality has come to signify a key criterion for improving port users' satisfaction in the maritime transport sub sector. The trend of policies introduced over the years in the sector such as liberalization, commercialization and port concession was born out of the need to address service efficiency through quality improvement in order to meet the increasing demand for seaborne trade and improve competitiveness. Parasuraman [1] expressed that meeting customers' expectations among other factors forms a major influence on customer assessment on service performance. With increase in seaborne transportation, compounded with competition, terminal operators are faced with the new challenge of maintaining and improving market share while providing efficient port services to vessels on call, freight owners and other port users. Service quality is a comparison of expectations with performance Tease [2]. With an import capacity of about 35 million tonnes per year [3]

Corresponding author: C. Onyemechi, Ph.D., reader, research field: maritime management technology. excluding oil, over which about $60 \%$ is cleared from the Lagos pilotage district, the need has always arisen for improvement of port service to improve efficiency in leading ports and also enhance competition in growing ports. Hence, the ability of the port to meet its users' demand becomes essential to maintain reliability.

The port industry has been growing at a phenomenal rate, especially since after the concession of ports in Nigeria. This growth has increased competition for established ports [4] which have naturally experienced reduced customer loyalty. Also transhipment of cargo has increased in competition. Ugboma et al. (2004) suggest that this increase has shifted the focus of service providers to the quality of service offered by port to their customers. Hence, understanding customer's perception and expectation of service quality at the port becomes a critical factor in the transfer of wealth among nations through the port as a nodal point.

The important role played by expectations in customers' evaluations of service has been observed in service quality literature $[5,6]$. In the maritime 
industry it has influenced customers' choice of port after making comparison among standards [4]. Since the transportation of goods by sea requires continuous improvement to meet the ever dynamic nature of ocean shipping and its related maritime operations [7], the service quality of ports must properly acknowledge the battery of service qualities to determine performance [1]. The increasing demand for transport and the ever expanding maritime shipping market has given rise to the developments experienced in the maritime industry. These developments have largely influenced the tonnage of goods controlled by the industry and the direction of tonnage has been largely influenced by the perception of port users. Several innovations have been employed in the past which has brought significant effects which most times manifest through increase in economies of scale [8].

A number of trends are currently reshaping international maritime transport and trade by altering costs, prices, logistics structures, supply chains and comparative advantages, these trends are also defining countries trade competitiveness and level of integration into the global transport and trading network [9]. The perceptions of port users about the quality of these factors are important for port choice [10].

For most developing countries these trends have been a major drive in marine transport development which has greatly contributed to the tonnage output of countries. According to UNCTAD [9] report there are several of these trends but the most influencing includes the demand for transport services, increasing fuelling of global economic growth and merchandise trade. Secondly, increased specialization in the supply of maritime transport services has gathered traction as developing countries continue to gain greater market share in maritime business Rodrigue, JP and Notteboom, T [10].

\section{Literature Review}

In today's port industry where competition is fierce and highly competitive, service quality evaluation has come to assume a key position as port users consider it in port selection decision. The measurement of service quality bymanagers has become essential to determine their position in meeting port user's requirement Langen, P. and Van Der Horst, M. [11]. As a result of competition, the nature of port services has continuously changed while the perception and expectations of port user's changes alongside, thereby causing a variation in port users' loyalty to a particular port. With these developments port operators and port authorities are faced with the responsibility of service quality measurement to meet contemporary challenges. With the boom in seaborne trade [12], increased traffic of vessels and the liberalization of the shipping market, terminal operators and port authorities are now faced with responsibilities which exceed only cargo handling at ports [10]. Competition has moved port operators from a position of isolation to the role of involvement into hinterland logistics (door-to-door), all in a bid to control larger market share of port users. Langden et al. [11] have suggested some reasons for this position by port operators. Firstly, an increasing amount of door-to-door costs are inland costs. Thus, the efficiency of hinterland transport becomes more important for the competitive position of port operators in supply chain. Secondly, whereas port operators have in general been able to improve terminal operations to accommodate increasing volumes (and ship sizes), dealing with these increased volumes has proved more difficult in hinterland transport. Thirdly, unlike the shipping industry that is dominated by relatively few global players, the number of firms involved in providing hinterland services is huge. Thus, there is need for the effective coordination of hinterland services [13]. Also, more of these reasons have been raised by Mona et al. (2016).

With the current competition in today's port environment service quality has become an inevitable factor for port success as it determines the retention of customers and further growth of customer base [1]. In the contribution of Ugboma et al [4] he supported this 
by saying that delivering quality service to port users is a must for success and survival in today's competitive port environment. Parasuraman et al. [1] reported that for a business to experience more new customers, more business with existing customers, fewer lost customers, more insulation from price competition and fewer mistakes requiring the performance of service, excellent service must be employed as strategy. Going by this, service quality therefore determines the level of business success. Ugboma et al. [4] contributed that service quality has been identified as a determinant of market share. Therefore, in the maritime industry, especially the seaport, service quality will determine the size of freight owners and ship agents controlled by an operator which will resultantly determine market share and profit.

\section{Methodology}

\subsection{Factor Analysis Technique}

Part of the objectives of this study is to identify port service quality attributes. This is achieved by exploring the variables (or dimensions) postulated and rated in the questionnaire as underlying the attributes. Many variables are considered and this necessitates the application of a variable reduction technique. This enables the identification of underlying or latent variables (factors) responsible for the phenomenon under investigation. This technique is achieved through Factor Analysis. The factors obtained are treated as explanatory variables and then used in regression analysis. According to Decoster (1998), Factor Analysis is collection of methods used to examine how underlying constructs influence the responses on a number of measured variables. There are basically two types of Factor Analysis: exploratory and confirmatory. EFA (Exploratory Factor Analysis) attempts to discover the nature of the constructs influencing a set of responses while CFA (Confirmatory Factor Analysis) tests whether a specified set of constructs is influencing responses in a predictive way.

Suppose the observed variables: $\mathrm{Y}_{1}, \mathrm{Y}_{2}, \ldots, \mathrm{Y}_{n}$ are linearly related to a smaller number of factors: $\mathrm{F}_{1}, \mathrm{~F}_{2}, \ldots, \mathrm{F}_{\mathrm{k}}$. In our study, we postulate that the observed variables represented by the cluster variables: Tangibles, Reliability, Responsiveness, Assurance, and Empathy, service quality dimensions related to extracted factors (from factor analysis model) according to the following equations:

$$
\begin{array}{ll}
Y_{\text {thrift_pay }}=\beta_{10}+\beta_{11} F_{1}+\beta_{12} F_{2}+e_{1} \\
\cdot \\
Y_{n}=\beta_{n, 0}+\sum_{n=1}^{n} \sum_{k=1}^{\infty} \beta_{i, k} F_{k}+e_{n}
\end{array}
$$

The error terms $e_{1}, e_{2}, \ldots, e_{n}$, serve to indicate the hypothesized relationships which are not exact. The parameters $\beta_{i, k}$ are referred to as loadings. For example, $\beta_{12}$ is called the loading of variable Reliability on factor $F_{2}$. Thus, variables that "load" in a similar pattern and significantly may be referring to some latent variables. Applying this technique, we identified the significant variables representing dimensions of service quality in Nigeria's seaports.

\section{Report of Findings}

\subsection{Inferential Statistics (Test of Hypotheses in the Study)}

In this section we present results of data analysis and test the hypotheses that govern this study. For example, Table 1 presents the results of Factor Analysis conducted to identify significant service quality dimensions and attributes. Thus from the table, Factor loadings on five hypothesized service quality dimensions according to literature, are examined. These dimensions are Tangibles, Reliability, Responsiveness, Assurance and Empathy.

A closer look at the scores (or "loadings" in the parlance of Factor Analysis) under "Tangibles" shows that the statistically significant attributes of this dimension are: "The terminal has modern cargo handling equipment", and "The port terminal has good access channel”. Scores above 0.4 are considered statistically significant for identifying dimensions and attributes in Factor Analysis. The cut-off value for 
Table 1 Identification of service quality attributes in ports using factor analysis (rotated factor matrix).

\begin{tabular}{|c|c|c|c|c|c|c|}
\hline Attributes & Tangibles & Reliability & Responsiveness & Assurance & Empathy & Uniqueness \\
\hline The terminal has modern cargo handling equipment & $0.6500^{*}$ & & & & & 0.6646 \\
\hline The terminal has good layout & 0.1931 & & & & & 0.4931 \\
\hline A variety of vessels call at the terminal & 0.3187 & & & & & 0.8037 \\
\hline The port terminal has good access & $0.392 *$ & & & & & 0.7471 \\
\hline There is frequency of ship-calls at the terminals & & 0.2193 & & & & 0.8641 \\
\hline The terminal is time efficient & & $0.5709 *$ & & & & 0.6554 \\
\hline The terminal operator delivers on promise & & $0.4379 *$ & & & & 0.6850 \\
\hline $\begin{array}{l}\text { Cargo discharge procedure at the terminal is } \\
\text { standard }\end{array}$ & & $0.679 *$ & & & & 0.5313 \\
\hline $\begin{array}{l}\text { The terminal is responsive with settlements of } \\
\text { claims }\end{array}$ & & & $0.7119 *$ & & & 0.4577 \\
\hline $\begin{array}{l}\text { The terminal responds quickly to vessel service } \\
\text { requirements }\end{array}$ & & & 0.3494 & & & 0.7639 \\
\hline Documentation procedures take little time & & & 0.3186 & & & 0.7441 \\
\hline $\begin{array}{l}\text { The effective government/private agencies } \\
\text { corporation }\end{array}$ & & & $0.5375 *$ & & & 0.6485 \\
\hline $\begin{array}{l}\text { The terminal workers are well } \\
\text { skilled/knowledgeable }\end{array}$ & & & & $0.5883^{*}$ & & 0.6396 \\
\hline There is effective security at the port & & & & $0.4007 *$ & & 0.7148 \\
\hline Rate of cargo damage at the terminal is minimal & & & & $0.4879 *$ & & 0.6129 \\
\hline The terminal is efficient in handling complaints & & & & 0.5111* & & 0.6280 \\
\hline The terminal provides value added service & & & & & $0.4652^{*}$ & 0.6858 \\
\hline $\begin{array}{l}\text { The terminal gives attention to customer unique } \\
\text { requirements }\end{array}$ & & & & & $0.4908 *$ & 0.6149 \\
\hline There is prompt information of problems & & & & & $0.474^{*}$ & 0.7235 \\
\hline The terminal gives after delivery services & & & & & $0.5925^{*}$ & 0.6129 \\
\hline
\end{tabular}

Source: authors own calculation. * significant correlation.

factor loadings according to Hulland [14], is 0.4. Therefore we note that Tangibles explained by the under listed attributes are a significant service quality dimension in Nigeria's ports. Similarly, Reliability is another identified "SERVIQUAL" dimension. Under this dimension, the attributes of importance are time efficiency in terminal operations, service delivery on promise by terminal operators and standard cargo discharge procedure. Thus based on the significant loading of scores under this dimension, these attributes (are significant and) are found to explain the reliability dimension of service quality. Another dimension also identified is "Responsiveness to port customer needs". Thus significant attributes in this case are: responsiveness of port to port customer claims and effective government and private agencies cooperation to ensure fluid port processes. The "Assurance" dimension is highly significant with all the attributes significant based on loaded scores. Thus important attributes under this dimension are: presence of skilled workers, security at the port, minimal cargo damage and efficiency in handling customer complaints. "Empathy" dimension is similarly loaded with significant attributes and these are provision of added value services at the ports, attention to customer unique requirements, prompt information and provision of after sales services.

It must be noted that these services (attributes) have now been more effective following the transfer of terminal operations from public (NPA) to private terminal operators. Competition has been introduced among the terminal operators who must provide quality services to be able to attract new customers and retain patronage of existing ones. New facilities have been provided in the ports through private investment. Therefore, the significant results recorded in 
“SERVIQUAL” dimensions are expected.

Based on the foregoing, two null hypotheses of the study have been rejected. These are namely: (i) that Tangibles, Reliability, Responsiveness, Assurance and Empathy are not significant service quality dimensions in Nigeria's ports, (ii) that the mean rating scores on corresponding attributes of service quality dimensions are not statistically different from zero.

\section{References}

[1] Parasuraman, A., Zeithaml, V. A., and Berry, L. 1994. "Reassessment of Expectations as a Comparison Standard in Measuring Service Quality: Implications for Future Research.” Journal of Marketing 58 (1): 111-24.

[2] Teas, R. K. 1993. "Expectations, Performance Evaluation, and Consumers' Perceptions of Quality.” Journal of Marketing 57 (4): 18-34.

[3] Onwuegbuchunam, D., and Okeudo, G. 2012. “An Evaluation of Nigeria's Seaborne Trade and Demand for Sea Transport.” European Journal of Business and Management 4 (13).

[4] Ugboma, C., Calistus, I., and Innocent C. O. 2006. “An Analytical Hierarchy Process for Port Selection Decision.” Maritime Economics \& Logistics 8 (3): 251-66.

[5] Bolton, R. N., and Drew, J. H. 1991. “A Longitudinal Analysis of the Impact of Service Changes on Customer
Attitude.” Journal of Market 55 (1): 1-9.

[6] Brown, S. W., and Swartz, T. A. 1989. "A Gap Analysis of Professional Service Quality.”Journal of Marketing 53 (2): 92-8.

[7] Harding, N. 2007. “On Lacanand the 'Becoming-Ness' of Organizations/Selves.” Organization 28 (11): 1761-73.

[8] Stopford, M. 1997. Maritime Economics. 2nd Edition. London: Routledge.

[9] UNCTAD. 2012. "World Investment Report 2012: Towards a New Generation of Investment Policies.” United Nations Conference on Trade and Development, New York and Geneva.

[10] Otteboom, T., and Rodrigue, J. P. 2004. "Inland Freight Distribution and the Sub-harborization of Port Terminals.” Paper presented at the ICLSP Conference, Dalian.

[11] Langen, P., and Van Der Horst, M. R. 2007. "Coordination in Hinterland Transport Chains: A Major Challenge for the Seaport Community.” International Association of Maritime Economists (IAME), Annual Conference Arthens 4-6.

[12] UNCTAD. 1998. "Handbook for Port Plannersin Developing Countries.”

[13] De Langen, P. W., and Chouly, A. 2004. "Hinterland Access Regimes in Seaports." European Journal of Transport and Infrastructure Research 4 (4): 361-81.

[14] Hulland, J. 1999. "Use of PLS in Strategic Management Research: A Review of Four Recent Studies.” Strategic Management Journal 20 (2): 195-204. 


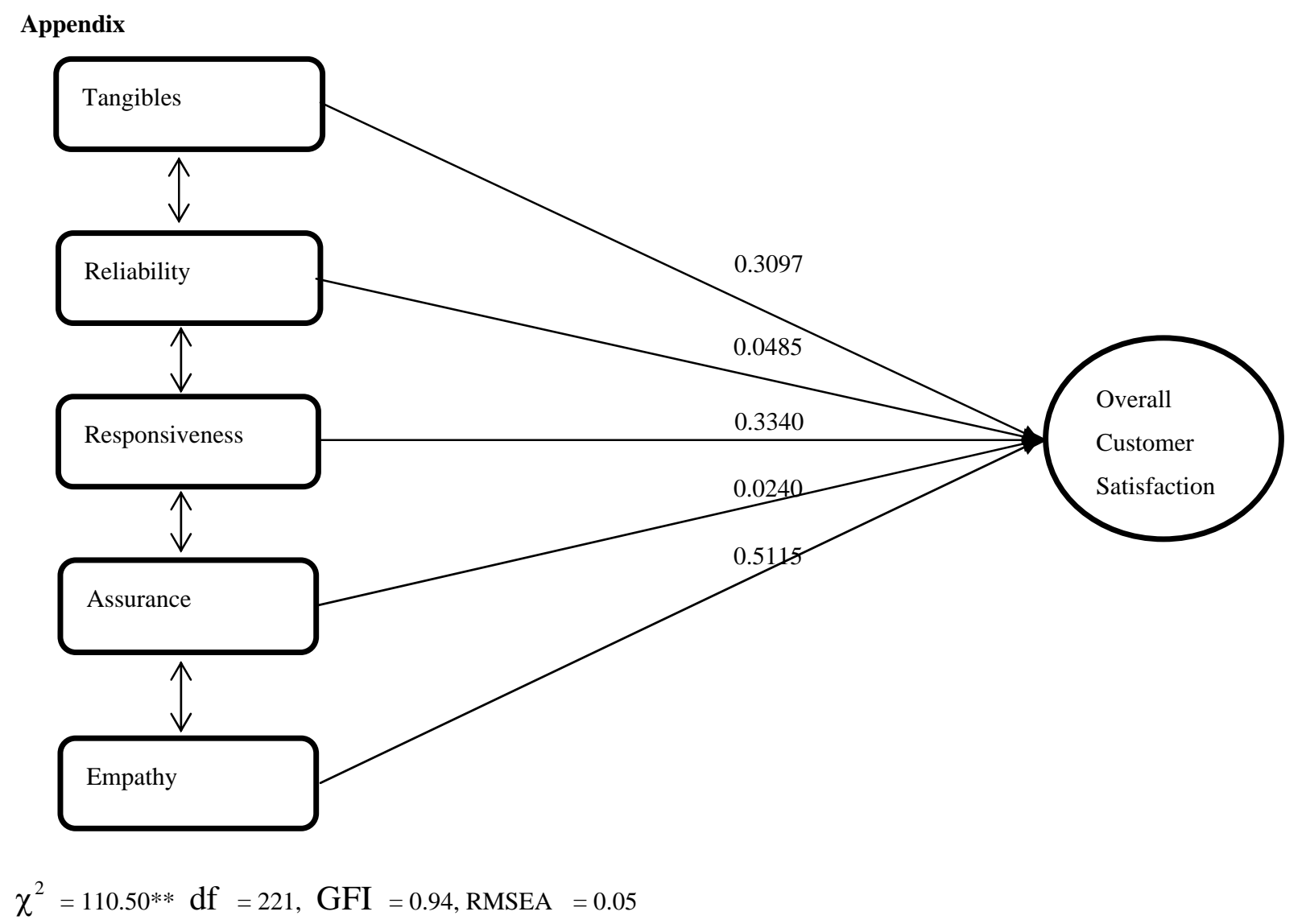

Fig. 1 Measures of Overall Customer satisfaction Using CFA 